$\xi=$

\title{
New reports of Daldinia species from Kolhapur and Raigad Districts (M.S.), India
}

\author{
Patil Anjali Rajendra ${ }^{1}$,*Patil Ketaki Prakash ${ }^{2}$, Patil Mansaram Sukhdeo ${ }^{3}$ \\ ${ }^{1}$ Department of Botany, Rajaram College, Kolhapur 416008 (M.S.) India \\ ${ }^{2}$ Department of Botany, Shivaji University, Kolhapur, 416008 (M.S.) India \\ ${ }^{3}$ Retd. Prof. and Head, Department of Botany, Shivaji University, Kolhapur, 416008 (M.S.) India \\ *Corresponding author E-mail:Ketupatil90@gmail.com
}

\begin{abstract}
Genus Daldinia Ces. \& De Not. Belongs to family Xylariaceae. Present paper describes ten species of Daldinia viz. D. "bakeri" taxon B sensu Dennis, D. concentrica (Bolton) Ces. \& De Not., D. cupra Starback, D. dennissii var. microspora Wollw. \& M. Stadler, D. palmensis M. Stadler, Wollw. \&Tichy, D. petriniae Y. M. Ju, J. D.Rogers and F. San Martin, D. raimundi M. Stadler, Venturella \&Wollw., D. theissenii Laessoe, J. Fourn. \& M. Stadler, D. bakeri Lloyd, D. loculata (Lev.) Sacc. Collected from Kolhapur and Raigad Districts of Maharashtra State, India.
\end{abstract}

Key words: Daldinia; Mycotaxonomy; Xylariaceae.

\section{Introduction}

Kolhapur and Raigad districts, a part of Western Ghats of Maharashtra, with ever green dense forests, are favourable habitat for many fungi. Genus Daldinia was erected by Italian mycologists, Cesati and De Notaris (1863) in honour of Agostino Daldini. (Ju, Rogers \& Martin, 1997). Distinctive character of Genus Daldinia is the globular shape and zonate arrangement of stroma, with alternative white or pale pithy layers, alternating with narrow black carbonous layers. The zones show different texture and colours. Genus Daldinia is represented in India by 07 species till date (Jamaluddin, et.al. 2004).Of the ten species described in the present work, only two species have been previously reported from India, but from different localities. Remaining 08 species make a new record to the fungi of India.

\section{Material and Methods}

Fresh material was collected during rainy season and preserved by drying in oven. Detail structures and microphotography was done using research microscope and routine laboratory techniques. Perispore dehiscence was tested with $10 \% \mathrm{KOH}$. Stromatal extractable pigments were studied using $10 \% \mathrm{KOH}$ and correct identification was done using A mycological colour chart (Rayner 1970). Photography was done using Nikon digital camera. Specimens were deposited in Herbarium Cryptogamae Indiae Orientalis (HCIO) New Delhi, India and accession numbers obtained. SEM was carried out at Physics Department, Savitribai Phule Pune University, Pune (M.S.), India.

\section{Result}

\subsection{Daldinia "bakeri” taxon B sensu Dennis}

Text Plate I: 1a -1d, Plate I: 1a-1b

Stroma turbinate (Cube like), sub-sessile, with perithecial outline exposed but deeply wrinkled due to drastic drying, with a deep median furrow, 1.7 - $2 \times 1.2-1.7 \times 0.4-0.7 \mathrm{~cm}$; surface dull reddish brown. granules immediately beneath surface with $\mathrm{KOH}$ extractable pigments absent; tissue between perithecia dark brown, pithy tissue base, darker zones dark brown, pithy to woody, 0.2 $0.5 \mathrm{~mm}$ thick, lighter zones golden brown, pithy, solid, 1-1.5 mm, ostioles umbilicate to slightly papillate; asci not seen; ascospores brown to dark brown, ellipsoid, inequilateral with narrowly rounded ends, 12.15 x 5-7.5 $\mu \mathrm{m}$, with straight germ slit; perispore dehiscent in $10 \% \mathrm{KOH}$.

Habitat: on dead wood, Rajaram College $16.6862^{\circ} \mathrm{N}, 74.2568^{\circ} \mathrm{E}$, Kolhapur (M.S.), 26. 7. 2012, HCIO No. 52010.

This species is known only from Central Africa (Stadler, et.al, 2014). It is a new report to the fungi of India.

\subsection{Daldinia concentrica (bolton) ces. \& de not}

Text Plate I: 2a -2d, Plate I: $2 \mathrm{a}-2 \mathrm{e}$

ESphaeria concentrica Bolton, Hist. Fung. Halifax III: 180. 1789; Bolton: Fr., Syst. Mycol. II: 331. 1823; non Wahlenberg,1812.

$\equiv$ Peripherostoma concentricum (Bolton: Fr.) Gray, Nat. Arr. Brit. Pl. I: 513. 1821.

इStromatosphaeria concentrica (Bolton: Fr.) Grev., Fl. Edinensis: 355.1824 .

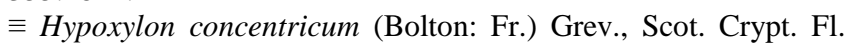
VI: pl. 324.1828. 
$\equiv$ Hemisphaeria concentrica (Bolton: Fr.) Klotzsch, Acad. Caes. Leop. Nova Acta 19: 241. 1843.

Stroma hemi-spherical to spherical, sessile, rarely sub-stipitate; surface even or frequently cracked into a fine network, 2 - 5 x 1.5 - 3 x $1-2 \mathrm{~cm}$, inconspicuous perithecia, outline brown; dull reddish brown granules immediately beneath the surface, with $\mathrm{KOH}$ extractable pigment dark purple (36), often rather dilute. Tissue between perithecia greyish brown to brown, pithy to woody, tissue below the perithecia layer composed of alternating zones, dark zones -dark brown, pithy to woody, persistent, $0.5-1 \mathrm{~mm}$ thick. Perithecia lanceolate, $1-2.2 \times 0.3-0.6 \mathrm{~mm}$. Ostioles slightly papillate. Asci not found. Ascospores brown to dark brown, ellipsoid- inequilateral, with narrow end, 12.5 (75) x $6.5-7.5 \mu \mathrm{m}$, with straight to slightly sigmoid germ slit, perispore dehiscent in $10 \%$ $\mathrm{KOH}$, appearing smooth, showing very faint ridges in SEM.

Habitat: on dead wood, Karanj $21.2149^{\circ} \mathrm{N}, 72.8434^{\circ} \mathrm{E}$, Uran Dist. Raigad (M.S.), 16. 08. 2014, HCIO No. 52011.

The present species has been report from many parts of India (Jamaluddin, et.al. 2004; Pande,A. 2008).

\subsection{Daldinia cuprea starback}

Text Plate I: $3 \mathrm{a}-3 \mathrm{~d}$, Plate I: $3 \mathrm{a}-3 \mathrm{f}$

= Daldinia granulosa Speg.,Anales Mus. Hist. Nat. Buenos Aires 19: 345. 1909.

Stroma usually cylindrical or sub - clavate, sub - sessile or with stout stipe usually bearing constricted ring, surface is smooth, colour is brown, after age it becomes dull brown or black; size of stroma is $1.9-3 \times 1.6-2 \times 0.4-1.5 \mathrm{~cm}$; without conspicuous perithecial outline; $\mathrm{KOH}$ extractable pigment is Brown Vinaceous (86); tissue between perithecia brown, pithy to woody tissue below perithecia layer composed of alternating zones, darker or zones of brown; asci not found. Ascospores are brown, ellipsoid inequilateral, with narrowly rounded ends, $12.5 \times 6.25-7.5 \mu \mathrm{m}$ with straight germ slit, spore length on convex slide; perispore smooth, dehiscent in $10 \% \mathrm{KOH}$; in SEM epispore is smooth.

Habitat: on dead wood, Karanj $21.2149^{\circ} \mathrm{N}, 72.8434^{\circ} \mathrm{E}$, Uran, Dist. Raigad (M.S.), 16. 08. 2014, HCIO No. 52012.

This species is known from south America and Africa (Stadler, et.al, 2014). It is a new report to the fungi of India.

\subsection{Daldinia dennissii var. microspora M. stadler\&wollw}

Text Plate II: 4a- 4d, Plate II: 3a - 3e,

= Hypoxylon stratosum Sacc., Syll. Fung. IX, p. 544. 1891.

= Daldinia stratosa (Sacc.) Sacc.\&Trott.,Syll . Fung. XXII, P. 327.1913.

Stromata semi-globose with inconspicuous perithecial outline, 2.5 x $1.5 \times 1 \mathrm{~cm}$; often becoming blackish in age, with dull reddish brown colour granules immediately beneath surface, with $\mathrm{KOH}$ extractable pigment Violet (32), the tissue between perithecia brown, pithy to woody, tissue below the perithecial layer composed of alternating zones, narrow, darker zones dark brown, ostioles slightly papillate; Asci not found; Ascospores dark brown, ellipsoid inequilateral, with narrowly rounded ends, $10.25 \times 7 \mu \mathrm{m}$, with germ slit on convex side, perispore dehiscent in $10 \% \mathrm{KOH}$ appearing smooth by SEM.

Habitat: on dead wood, Rajaram College $16.6862^{\circ} \mathrm{N}, 74.2568^{\circ} \mathrm{E}$ Kolhapur (M.S.), 03. 08. 2012, HCIO No. 52013.

This species is known from South Australia, Zealand, Polynesia, South Africa (Stadler, et. al., 2014). It is a new report to the fungi of India.

\subsection{Daldinia palmensis M. stadler, Wollw. \& Tichy}

Text Plate II: $5 \mathrm{a}-5 \mathrm{~d}$, Plate II: $5 \mathrm{a}-5 \mathrm{~g}$

Stomata semi-globose, sessile stromatal surface is brown, blacking with age ; size of stroma is $1.9-6 \times 1.8-5 \times 1.3 \mathrm{~cm}$; KOH extractable pigment is Vinaceous Purple (101) ; tissue between perithecia brown and below the perithecial layer composed of alternating zones darker zones is brown, lighter zones gray coloured; perithecial lanceolate; ostioles papaillate; Asci not found; Ascospores brown, ellipsoid- inequilateral; broadly to narrow rounded ends, $10-15 \times 5-7.5 \mu \mathrm{m}$, germ slit straight or lightly sigmoid, perispores dehiscent in $10 \% \mathrm{KOH}$, appearing smooth by SEM.

Habitat: on dead wood, Pal Devrai, Tal.- Gargoti $16.3174^{\circ} \mathrm{N}$, $74.1387^{\circ}$ E, Dist Kolhapur (M.S.), 06. 09. 2014, HCIO No. 52014. This species is known from Canary Islands (Stadler, et.al., 2014). It is a new report to the fungi of India.

\subsection{Daldinia petriniae. Y. M. Ju, J. D. Rogers and F. San Martin}

Text Plate II: 6a-6d, Plate III: 6a -6f

$=$ ? Daldinia concentrica f. confluens C.G. Lloyd, Mycol. Writings 5, Large Pyrenomycetes: 25, 1919.

Stromata hemi-spherical, sessile or sub-sessile, surface is dark brick coloured, blackening with age; size of stroma is $4-1 \times 2-1$ x $0.5-1.5 \mathrm{~cm} ; \mathrm{KOH}$ extractable pigment initially Livid Purple (81); tissue between perithecia brown, pithy to woody and below perithecia layer composed of alternating zones, darker zones dark brown, pithy to woody, $0.3-0.7 \mathrm{~mm}$ thick, lighter zones brown, pithy to woody, perithecia lanceolate, ostioles papillate. Asci not found, Ascospores are brown to dark brown, ellipsoid - inequilateral, with narrowly rounded ends, $12.5-15 \times 7.5 \mu \mathrm{m}$, with straight germ slit, spore length on convex side; perispore dehiscent in $10 \%$ $\mathrm{KOH}$, smooth by SEM.

Habitat: on dead wood, Rajaram College $16.6862^{\circ} \mathrm{N}, 74.2568^{\circ} \mathrm{E}$, Kolhapur (M.S.), 01. 08. 2015, HCIO No. 52015. This species is known from tropical regions of the world (Stadler, et.al., 2014). It is a new report to the fungi of India.

\subsection{Daldinia raimundi M. Stadler, Venturella \& Wollw}

Text Plate III: $7 \mathrm{a}-7 \mathrm{~d}$, Plate III: $7 \mathrm{a}-7 \mathrm{e}$

Stromata sub-globose, sessile, $4.2 \times 3.9 \times 1.5 \mathrm{~cm}$, surface purplish brown in young stromata, later becoming dark brown and finally blackening, with inconspicuous perithecial outline; stromatal pigments in KOH Purplish Gray (128), tissue between perithecia brown, pithy to woody and below the perithecial layer composed of alternating zones, darker zones dark brown, pithy to woody, 0.1 - $0.25 \mathrm{~mm}$ thick, lighter zones white to greyish brown, becoming pithy to woody, persistent, $0.8-1.5 \mathrm{~mm}$ thick, asci not found. Ascospores dark brown, $10-12.5$ x $5-7.5 \mu \mathrm{m}$; germ silt straight; perispore dehiscent in $10 \% \mathrm{KOH}$, smooth by SEM.

Habitat: on dead wood, Patgaon $17.32638^{\circ} \mathrm{N}, 74.30306^{\circ}$ E, DistKolhapur (M.S.), 06. 09. 2014, HCIO No. 52016.

This species is known from South Western Europe and Mediterranean (Stadler, et.al, 2014). It is a new report to the fungi of India.

\subsection{Daldinia theissenii Laessoe, J. Fourn. \& M. Stadler}

Text Plate III: $8 \mathrm{a}-8 \mathrm{~d}$, Plate IV: $8 \mathrm{a}-8 \mathrm{f}$

Misapplied name $=$ Daldinia clavata sensu ju et. al.

Stromata hemispherical to somewhat clavate, sub-sessile, surface is brown in colour; size of stroma is $5.5 \times 4 \times 2.6 \mathrm{~cm}$; KOH extractable pigment is Vinaceous Purple (101) ; tissue between perithecia gray and brown, tissue below perithecial layer composed of alternating zones darker zones is dark brown, $0.2-0.4$, lighter zone is white coloured; asci not found. Ascospores are ellipsoid inequilateral with broad to less frequently narrow end; 10.5 $16.25 \times 7.5-8.75 \mu \mathrm{m}$, with perispore dehiscent in $10 \% \mathrm{KOH}$, SEM shows conspicuous transverse striations.

Habitat: on dead wood, Amba $16.9060284^{\circ}$

N, $73.7440942^{\circ}$ E, Tal- Shahuwadi, Dist- Kolhapur (M.S.), 18. 10. 2014, HCIO No. 52017.

This species has been reported from South America (Stadler, et.al, 2014). It is a new report to the fungi of India.

\subsection{Daldinia bakeri Lloyd}

Text Plate III: 9a-9c, Plate IV: 9a-9c 
Stromata irregular, pulvinate to almost semi-globose, with inconspicuous perithecia; $1.5 \times 1.5 \times 1.2 \mathrm{~cm}$, surface dark brownish ; KOH extractable pigment Dark Livid (80); tissue between perithecia brown , concentric zones white, $0.2-0.3 \mathrm{~mm}$ thick, lighter zones dull whitish, perithecia lanceolate; ostioles slightly papillate; asci not found; Ascospores dark brown, elliposiod, slightly inequilateral to equilateral, with broad to rounded end, $15-16 \mathrm{x}$ $10-12.5 \mu \mathrm{m}$, with germ slit; perispore indehiscent in $10 \% \mathrm{KOH}$.

Habitat: on dead wood, Rajaram College $16.6862^{\circ} \mathrm{N}, 74.2568^{\circ} \mathrm{E}$, Kolhapur (M.S.), 15. 09. 2012. HCIO No. 520108.

The present species has been reported from many parts of India (Jamaluddin, et.al. 2004; Pande,A. 2008).

\subsection{Daldinia loculata (Lev.) Sacc}

Text Plate IV: 10a-10c, Plate V: 10a-10c

= Sphaeria loculata Lév., Ann. Sci. Nat. Bot., sér. III, 3: 47. 1845. Stromata spherical to hemispherical, sessile or nearly so solitary, conspicuous perithecial outlines, 1-1.6 $\times .8-1 \times 0.6 \mathrm{~cm}$; surface brown, blackened in age. $\mathrm{KOH}$ extractable pigment is Livid Purple (81), tissue between perithecial layers show alternating zones, darker zones brown in colour, lighter zones greyish brown in colour, perithecia lanceolate, ostioles papillate; asci not found ;Ascospores are dark brown in colour, ellipsoid - equilateral to slightly inequilateral, with broadly rounded ends, $11-12 \times 6.5 \mu \mathrm{m}$, with grem slit, perispore is indehiscent $10 \% \mathrm{KOH}$; epispore is smooth in SEM.

Habitat: on dead wood, Rajaram College $16.6862^{\circ} \mathrm{N}, 74.2568^{\circ} \mathrm{E}$, Kolhapur, 03. 09. 2008. HCIO No. 52019.
This species has been reported from Scandinavia and in North America (Stadler, et.al, 2014). It is a new report to the fungi of India.

\section{Discussion}

Genus Daldinia is known by 47 species in the world (Stadler, M., Laessoe T., Fournier J., Decock C., Schmieschek, B., Tichy, H. V. \&Persoon, D., 2014). Seven species are known from India (Jamaluddin, et. al. 2004) and two species in Maharashtra (Alka Pande, 2008). After studying and comparing all the taxa, collected during the present work, with the known species they were identified as D. "bakeri" taxon B sensu Dennis, D. cuprea Starback , D. dennissii var. microspora M. Stadler \& Wollw., D. loculata (Lev.) Sacc., D. palmensis M. Stadler, Wollw. And Tichy, D. petriniae Y.M. Ju, J. D. Rogers and F. San Martin, D. raimundi M.Stadler, Venturella and Wollw. and D. theissenii Laessoe, J. Fourn. and M. Stadler. Eight species have been reported for the first time from India and two species viz. D. concentrica (Bolton) Ces. \& De Not.and Daldinia bakeri Lloyd have been reported for the first time from the study area.

\section{Acknowledgement}

I would like to acknowledge the help of Dr. B. T. Dangat, Ms.Reshma Nagarakatti, Ms.Madhuri Kamble, Ms.Sunita Patil, Mr.Suraj Patil, Mr.Sushant Kirmite, Mr.Ramprasad Narewadi, Mr.Pandurang Bagam and Mr.Yogesh Patil during the field work.

Table 1:Daldinia Spp. with Dehiscent Spores

\begin{tabular}{lllc}
\hline & Species & Ascospores & Stromatal Pigment \\
\hline 1 & Daldinia "bakeri” taxon B sensu & $12.15 \times 5-7.5 \mu \mathrm{m}$ & No colour \\
2 & D. concentrica & $12.5(75) \times 6.5-7.5 \mu \mathrm{m}$ & Dark purple (36) \\
3 & D. cupra & $12.5 \times 6.25-7.5 \mu \mathrm{m}$ & Brown Vinaceous (86) \\
4 & D. dennissii var. microspora & $10.25 \times 7 \mu \mathrm{m}$ & Violet (32) \\
5 & D. palmensis & $10-15 \times 5-7.5 \mu \mathrm{m}$ & Vinaceous Purple (101) \\
6 & D. petriniae & $12.5-15 \times 7.5 \mu \mathrm{m}$ & Livid Purple (81) \\
7 & D. raimundi & $10-12.5 \times 5-7.5 \mu \mathrm{m}$ & Purplish Gray (128) \\
8 & D. theissenii & $10.5-16.25 \times 7.5-8.75 \mu \mathrm{m}$ & Vinaceous Purple (101) \\
\hline
\end{tabular}

Table 2:Daldinia Spp. with Indehiscent Spores

\begin{tabular}{llll}
\hline & Species & Ascospores & Stromatal Pigment \\
\hline 9 & D. bakeri & $15-16 \times 10-12.5 \mu \mathrm{m}$ & Dark Livid (80) \\
10 & D. loculata & $11-12 \times 6.5 \mu \mathrm{m}$ & Livid Purple (81), \\
\hline
\end{tabular}




\section{Text Plate No. I}

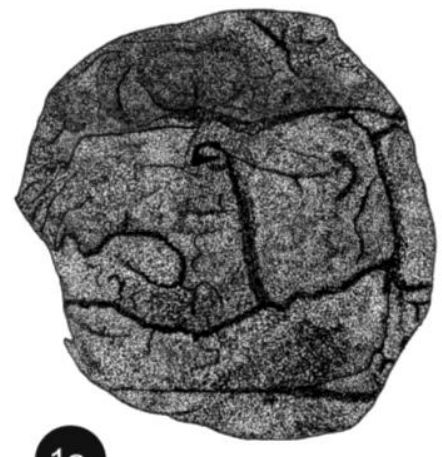

1 a

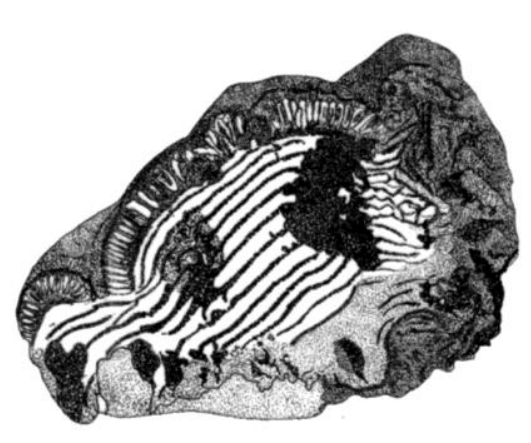

(1b) $0.13 \mathrm{~cm}$
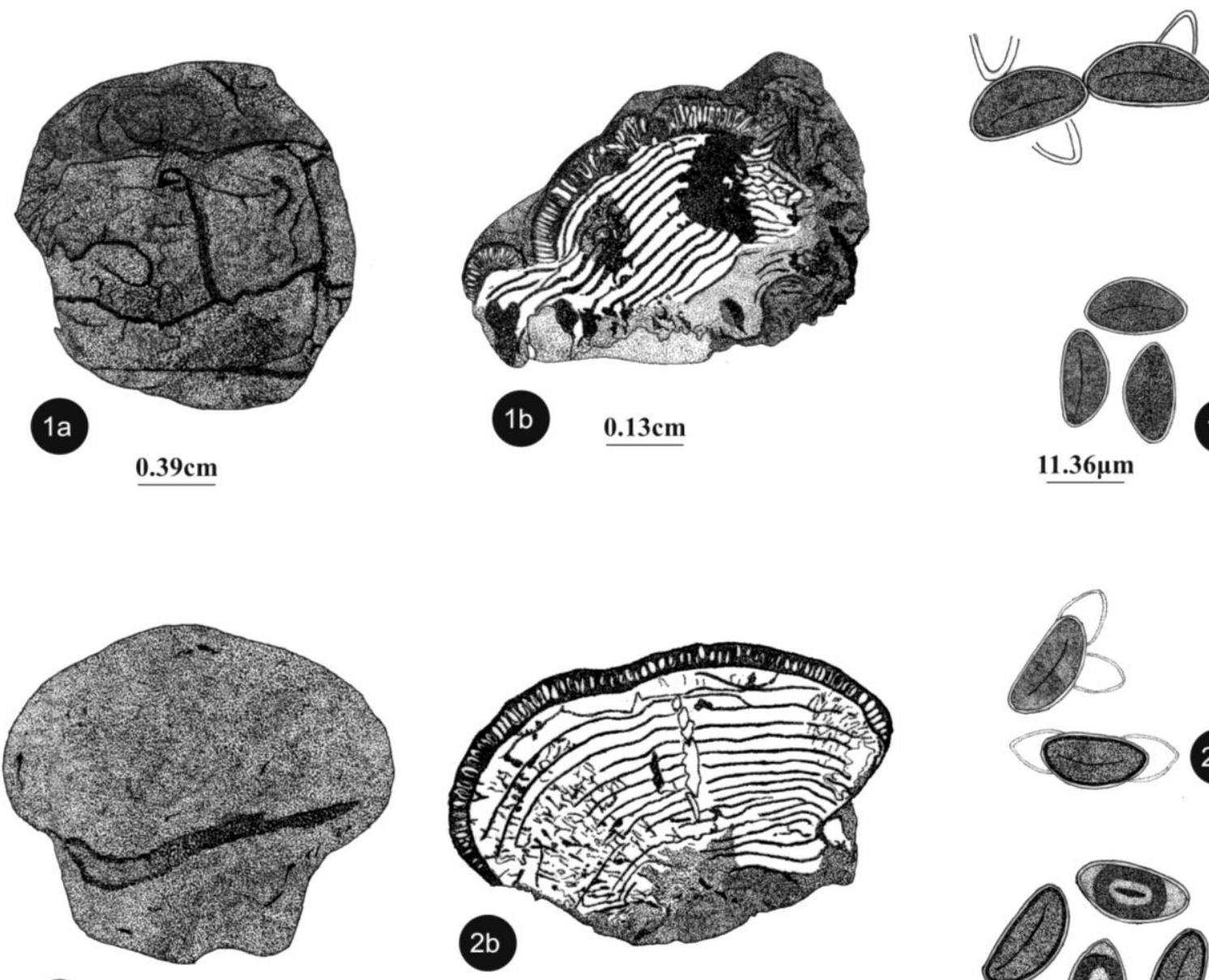

$0.57 \mathrm{~cm}$

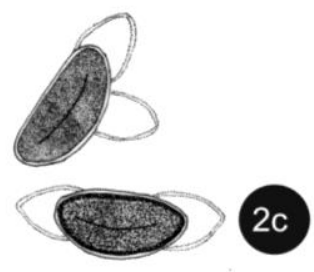

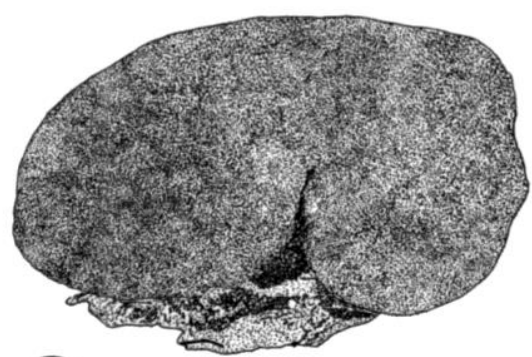

$3 a$

$0.78 \mathrm{~cm}$

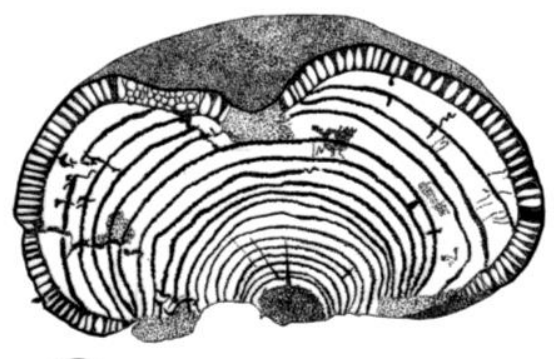

3b $0.5 \mathrm{~cm}$
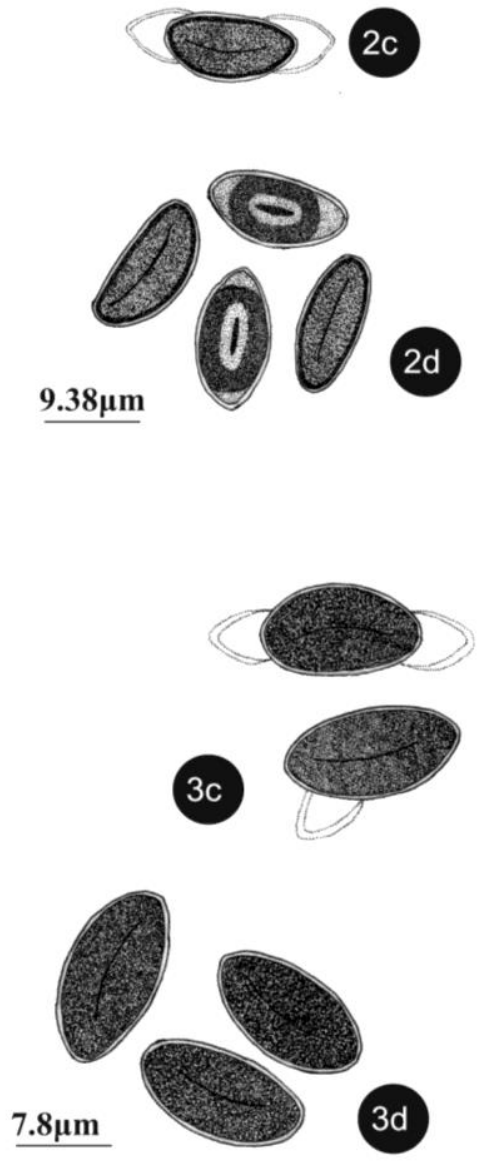

Figure no. a-Habit; b- Section of stroma and c-d-Ascospores of,

Fig.1 : Daldinia “bakeri” taxon B sensu Dennis

Fig. 2 : Daldinia concentrica (Bolton) Ces. \& De Not

Fig. 3 : Daldinia cuprea Starback 


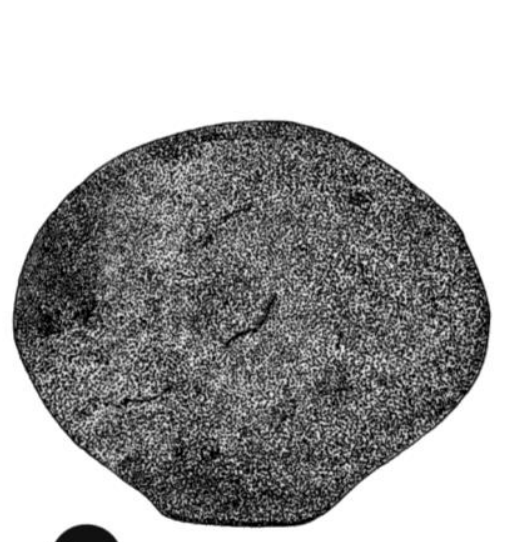

$4 a$

\section{Text Plate No. II}

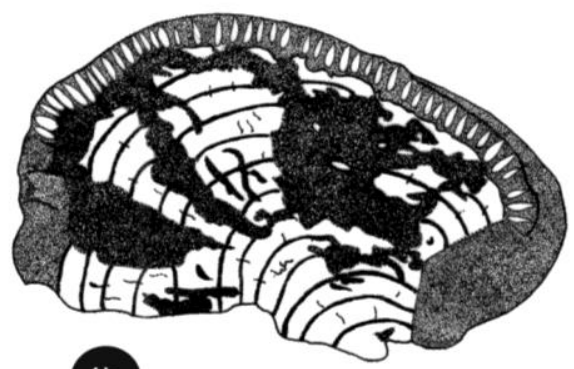

$4 b$

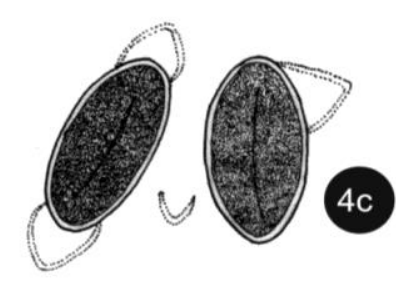

4d
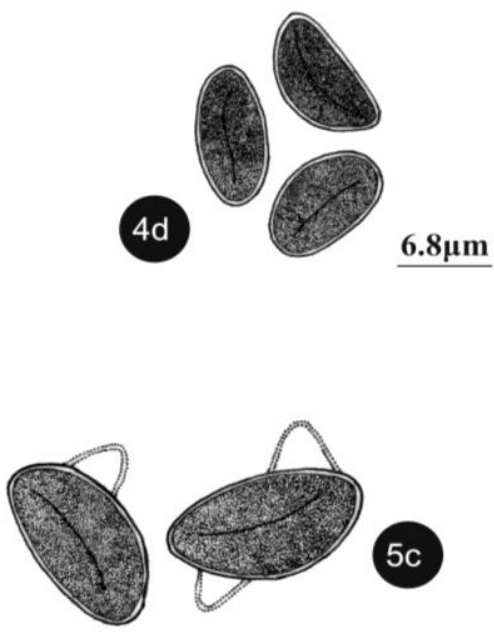

(5c

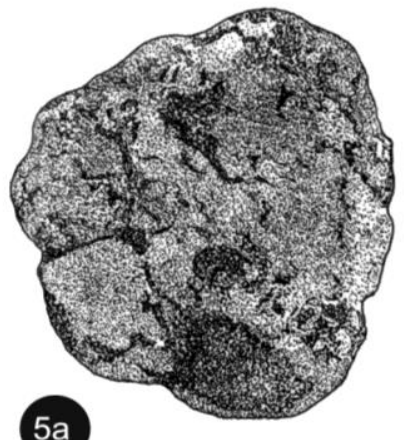

$1.4 \mathrm{~cm}$

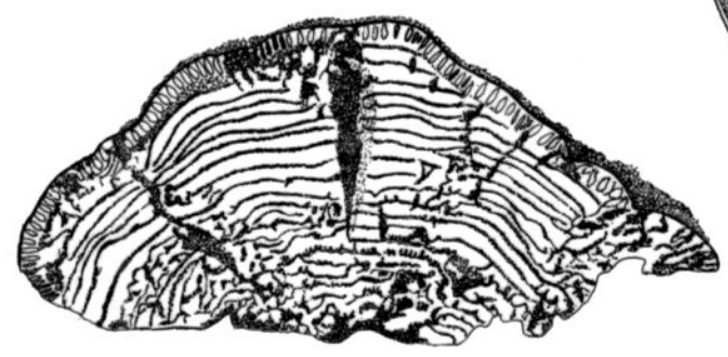

$5 b$

$0.39 \mathrm{~cm}$

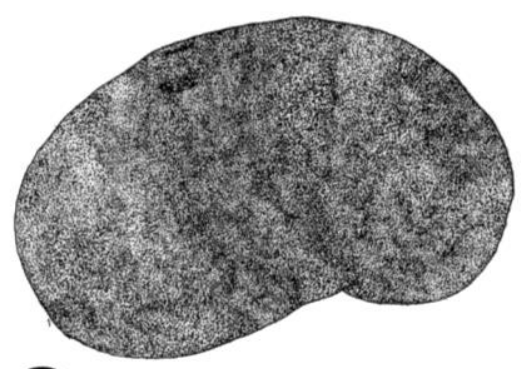

$6 a$

$1.21 \mathrm{~cm}$

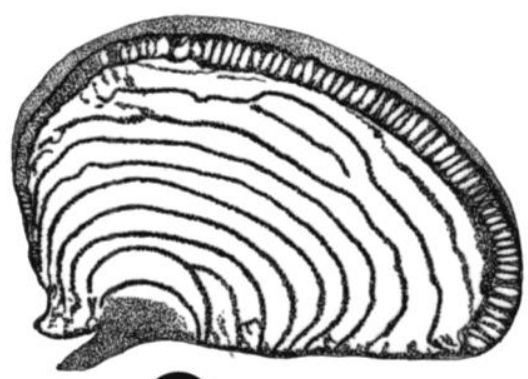

$6 b$

$\underline{0.42 \mathrm{~cm}}$
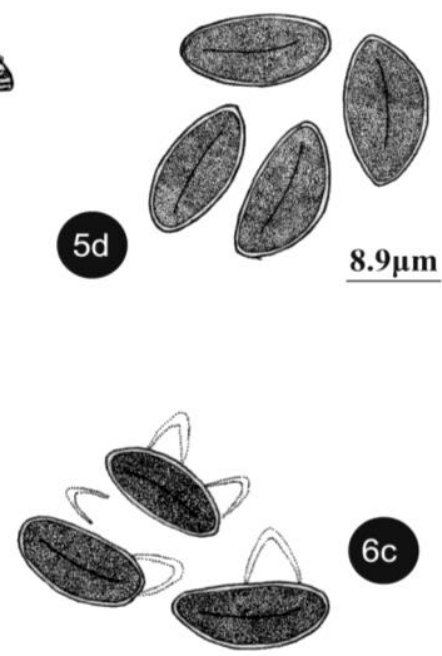

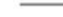

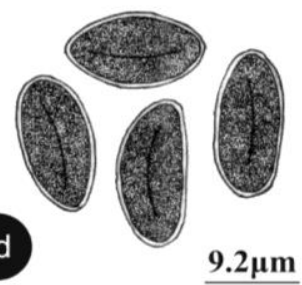

Figure no. a - Habit; b- Section of stroma and $\mathrm{c}-\mathrm{d}$ - Ascospores of,

Fig.4 : Daldinia dennisii var. microspora Wollw \& M. Stadler.

Fig.5 : Daldinia palmensis M. Stadler, Wollw. \& Tichy

Fig.6 : Daldinia petriniae Y.M.Ju, J.D.Rogers and F. San Martin 


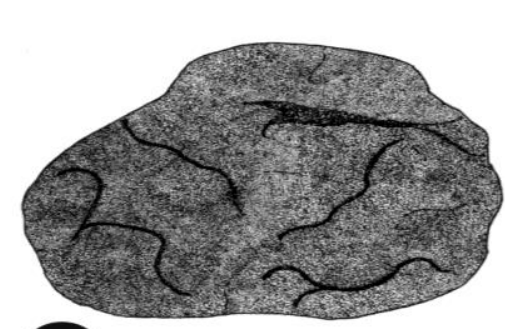

$7 a$

\section{Text Plate No. III}

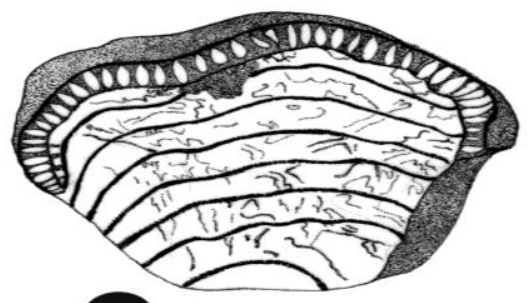

$7 \mathrm{~b}$
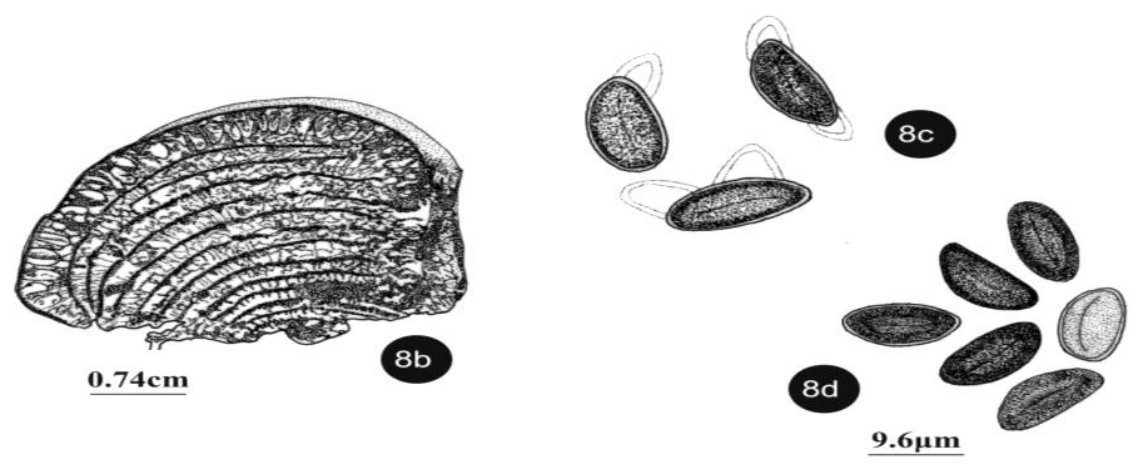

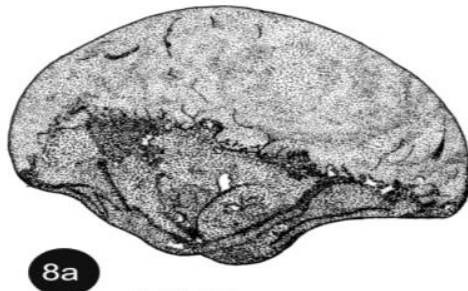

$1.61 \mathrm{~cm}$
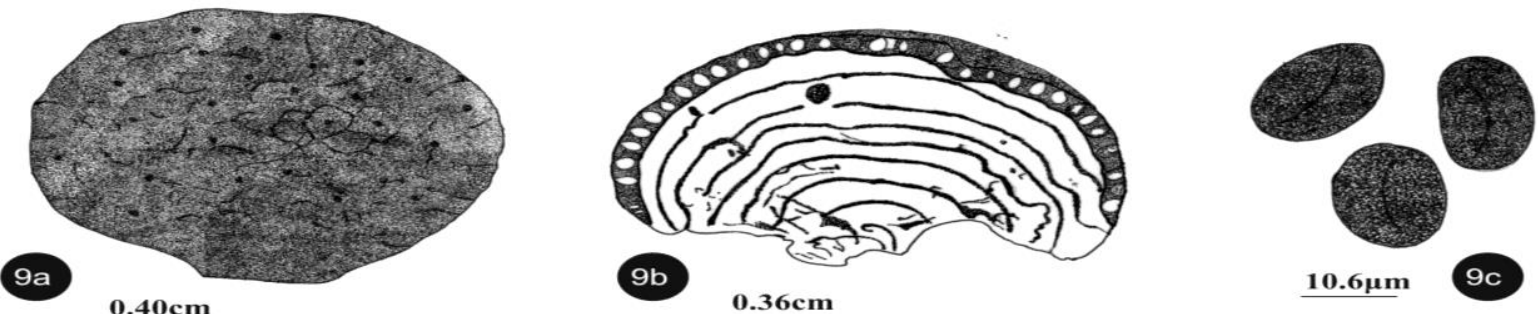

Figure no. a - Habit; b- Section of stroma and c-d-Ascospores of,

Fig. 7 : Daldinia raimundi M. Stadler, Venturella \& Wollw

Fig. 8 : Daldinia theissenii Læssøe, J. Fourn. \& M. Stadler

Fig.9 : Daldinia bakeri Lloyd

\section{Text Plate No. IV}

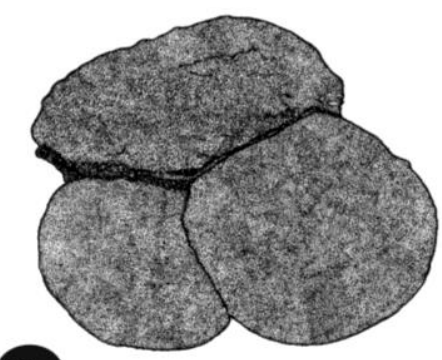

$10 \mathrm{a}$

$0.4 \mathrm{~cm}$

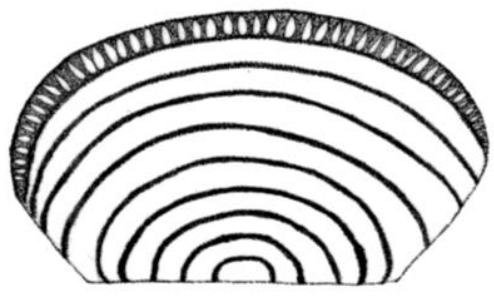

10b $\quad 0.18 \mathrm{~cm}$

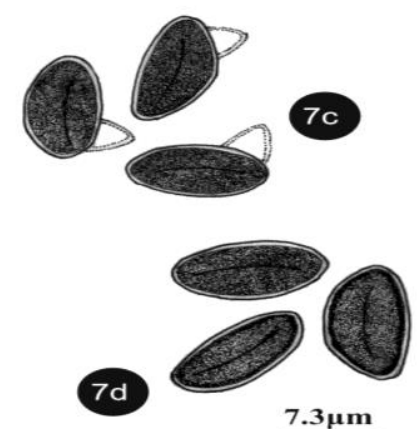

$\underline{9.6 \mu \mathrm{m}}$

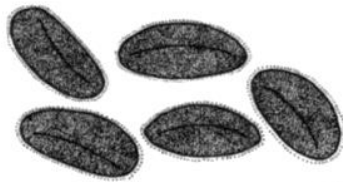

$9.2 \mu \mathrm{m}$

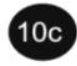

Figure no. a - Habit; b- Section of stroma and c-Ascospores of,

Fig.10 : Daldinia. loculata (Lév.) sacc 


\section{Plate No. I}
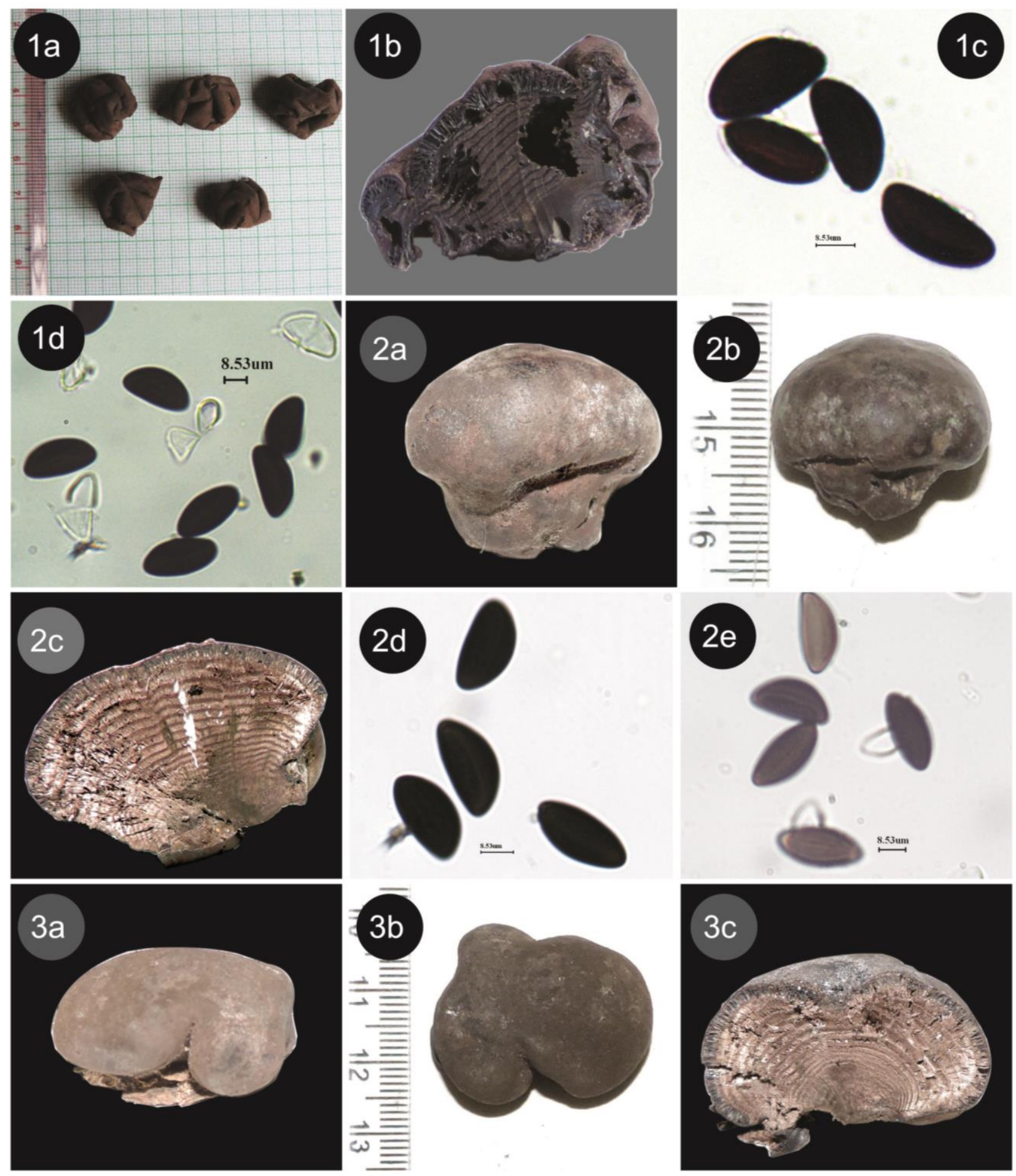

1a-d: Daldinia "bakeri" taxon B sensu Dennis- a.Habit; b. section of stroma; c-d. dehiscent ascospores., 2a-e: Daldinia concentrica (Bolton) Ces. \& De Not ; a-b.Habit; c. section of stroma; d-e. dehiscent ascospores., 3a-f: Daldinia cuprea Starback a-b.Habit; c. section of stroma; 


\section{Plate No. II}

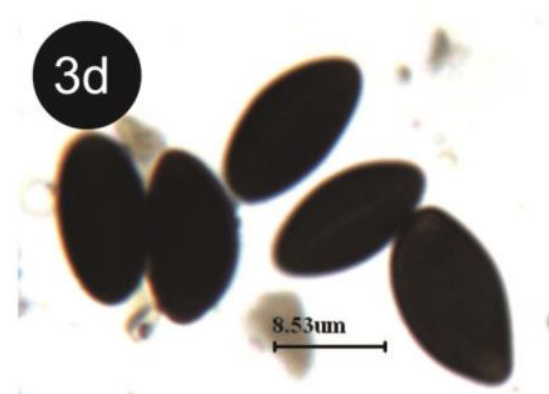

$3 e$

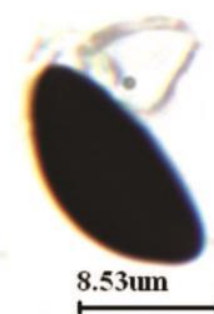

1
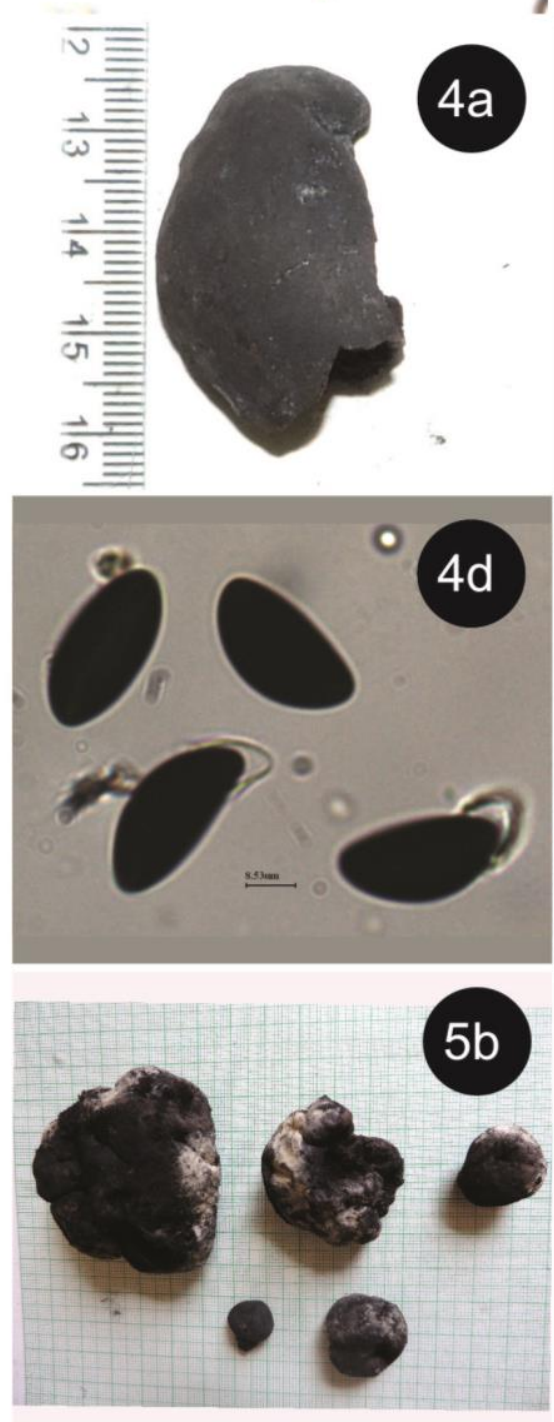
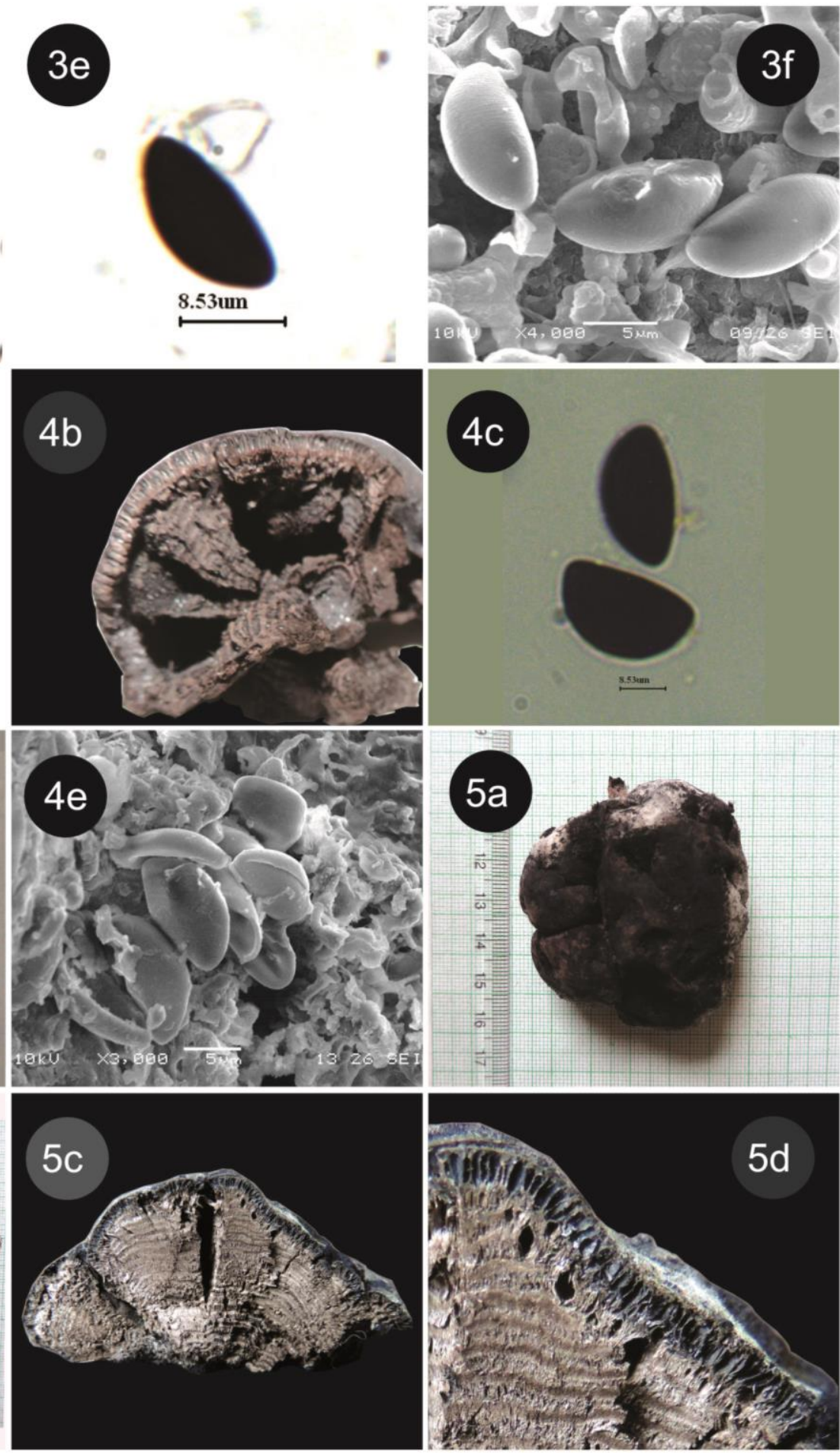

d-e. dehiscent ascospores; f. SEM ascospores., 4a-e: Daldinia dennissii var. microspora

M. Stadler \& Wollw. a.Habit;b. section of stroma; c-d. dehiscent ascospores;

e. SEM ascospores.5a-g : Daldinia palmensis M. Stadler, Wollw. \& Tichy a-b. Habit; c-d.section of stroma and Perithecia; 


\section{Plate No. III}

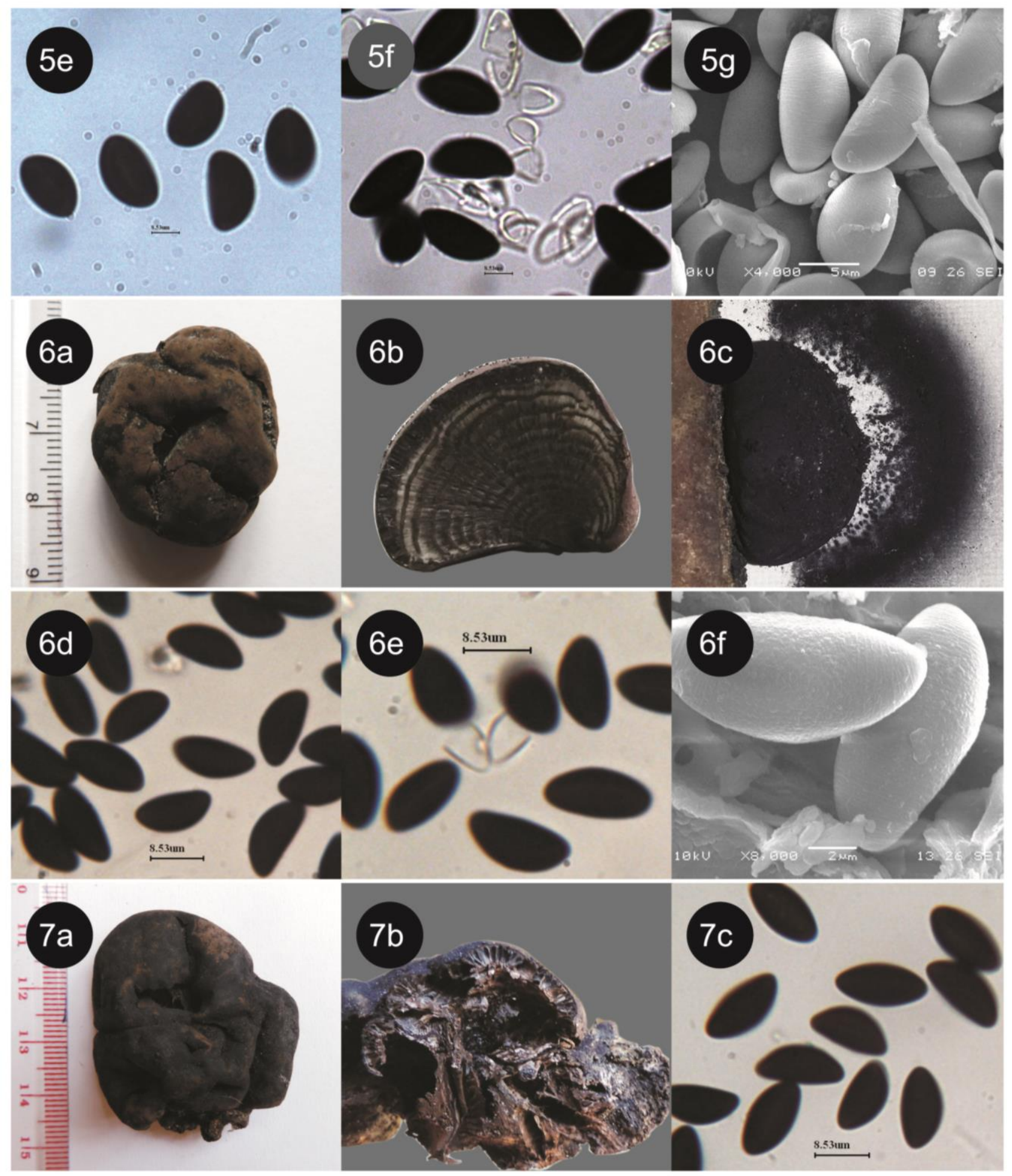

e-f. dehiscent ascospores; g. SEM ascospores. 6a-f : Daldinia petriniae Y.M.Ju, J.D.Rogers and F. San Martin a.Habit; b. Section of stroma; c.Sporulation; d-e dehiscent ascospores; f. SEM ascospores. 7a-e : Daldinia raimundi M. Stadler, Venturella \& Wollw a.Habit; b.section of stroma; c-d. Dehiscent ascospores; 


\section{Plate No. IV}

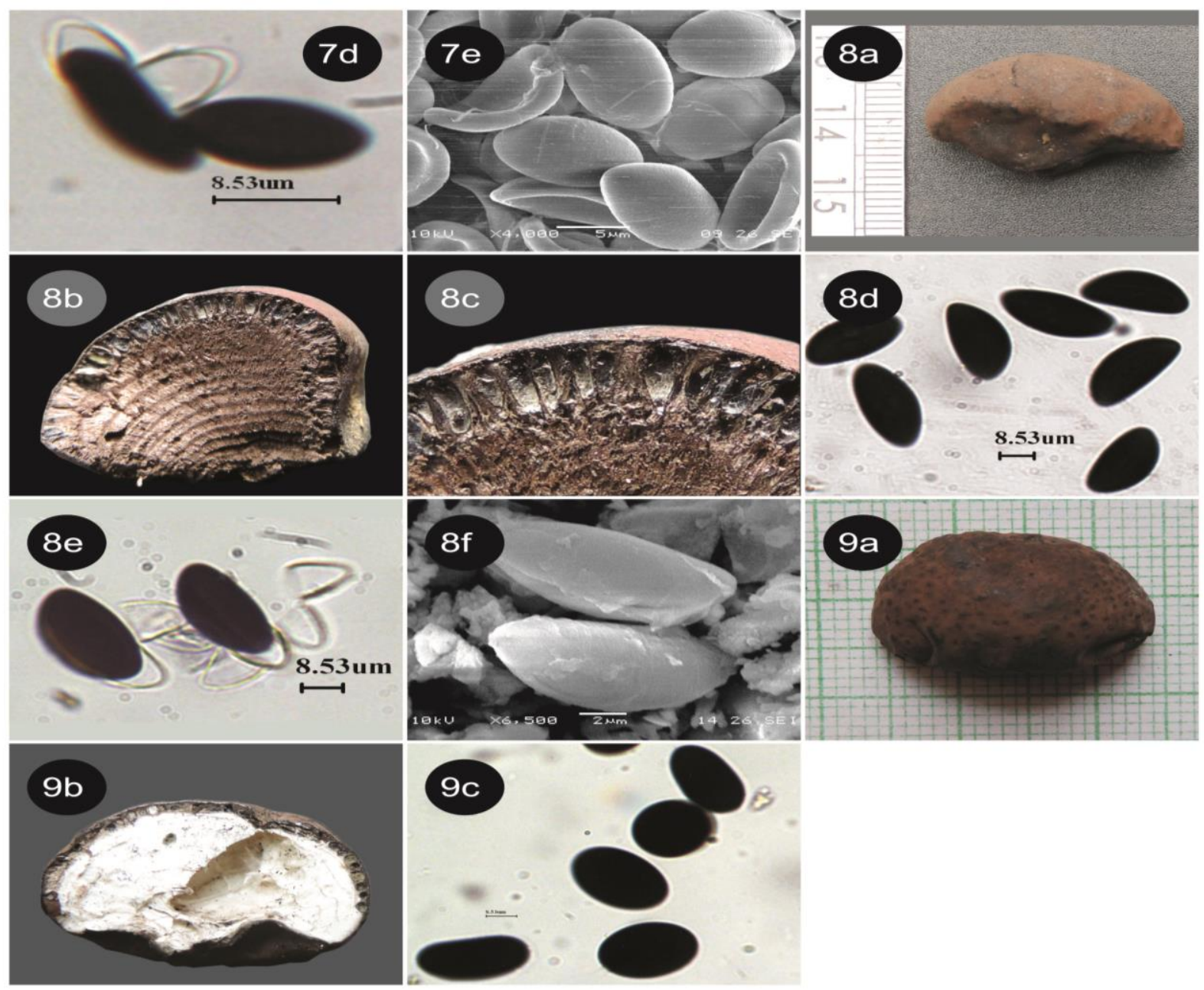

e. SEM ascospores. 8a-f : Daldinia theissenii Læssøe, J. Fourn. \& M. Stadler

a.Habit; b-c. Section of stroma and perithecia;d-e. Dehiscent ascospores; f. SEM ascospores.

9a-c : Daldinia bakeri Lloyd; a. Habit; b. Section of stroma; c. Ascospores;

\section{Plate No. V}
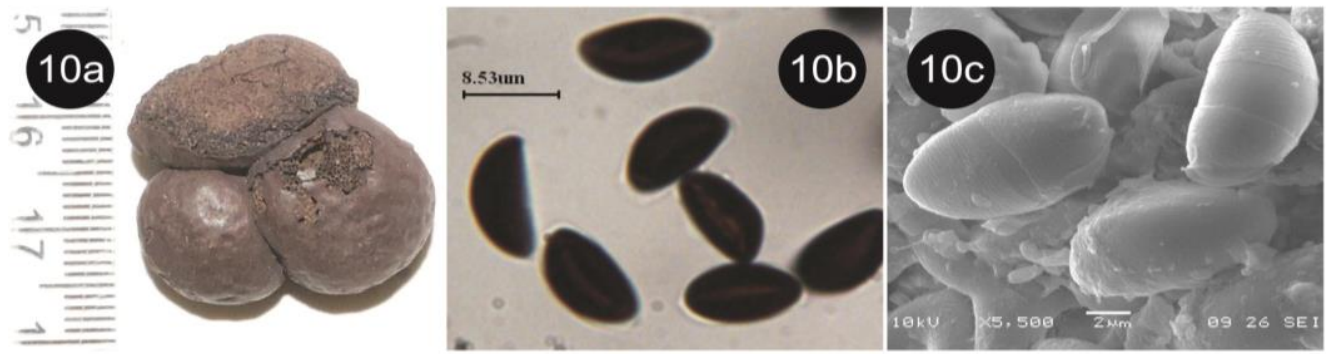

10a-c : Daldinia. loculata (Lév.) sacc a. Habit; b.Ascospores; c.SEM ascospores. 


\section{References}

[1] Dennis RWG (1956) Some Xylarias of Tropical America, KewBulletin, 401 - 444. http://dx.doi.org/10.2307/4109126.

[2] Dennis RWG (1957) Some Xylariales of Tropical America, KewBulletin, 2; 297 - 333. http://dx.doi.org/10.2307/4114428.

[3] Jamaluddin, Bilgrami KS and Rizwi MA (1991) fungi of India List and References, Today and tomorrow's Printers \& Publishers, New Delhi.

[4] Jamaluddin, Goswami MG, Ojha BM (2001) fungi of India, scientific Publication (India) Jodhpur.

[5] Ju YM, Rogers JD \& Martin FS (1997) A Revision of the Genus Daldinia, Mycotaxon 61; 243-293.

[6] Pande A. (2008) Ascomycetes of Peninsular India, Scientific Publishers, Jodhpur.

[7] Rayner RW (1970) A Mycological Colour Chart. Commonwealth Mycological Institute, kew.

[8] Rogers JD (1979) The Xylariaceae: Systematic, Biological and Evolutionary aspects, Mycologia 71(1), 1-42. http://dx.doi.org/10.2307/3759218.

[9] Stadler M, Baumgartner M \&Wollweber H (2001) three new Daldinia species with yellowish stromata pigment, Mycotaxon 80; 179-196.

[10] Stadler M, Baumgartner M, Wollweber H, Ju YM \& Rogers JD (2001) Daldinia decipiens sp.nov. and Notes on some other European Daldinia spp. Inhibiting betualaceae, Mycotaxon 80; 167-177.

[11] Stadler M, Laessoe T, Fournier J, Decock C, Schmieschek B, Tichy HV \& Person D (2014) A Polyphasic taxonomy of Daldinia (Xylariaceae) CBS-KNAW Fungal Biodiversity Centre, Utrecht, The Netherland An institute of the royal Netherland Academy of Art and Science.

[12] Thind KS, Dargan JS (1978) Xylariaceae of India, part IV. The Genus Daldinia. Kavaka 6; 15-24.

[13] Vasilyeva L \& M (2008) Pyrenomycetes of the Russian Far East. 3. Three New Daldinia species (Xylariaceae), Mycotaxon 104; 287 296.

[14] Whalley AJS (1996) The xyalriaceous way of life; Mycological research 100(8); 897-922. 